\title{
Risky sexual behavior practice and associated factors among secondary and preparatory school students of Aksum town, northern Ethiopia, 2018
}

\author{
Alem Girmay ${ }^{*}$ and Teklewoini Mariye
}

\begin{abstract}
Objective: As adolescence is a stage in which human beings face once throughout a lifetime and it is the experimental period for this reason risky sexual behavior is common among young people, and it has several sexual and reproductive health consequences. But it doesn't get enough attention the status of risky sexual behavior practice and factors' contributing to it, so this study aimed to identify the prevalence of risky sexual behavior and factors associated with it.

Results: From the total respondents 115 (23.7\%) had history of sexual intercourse and the mean age for sexual initiation is $15.48 \pm 1.99$ year. From whom 110 (98.2\%) had sexual contact below the age of 18 and only 68 (60.8\%) initiate first sex by their own willing. Overall $97(19.6 \%)$ had practiced risky sexual behaviors. Students not facing peer pressure were 0.36 times less likely to develop risk sexual behavior $(A O R=0.357,95 \% \mathrm{Cl} 0.172,0.744)$.
\end{abstract}

Keywords: Risk sexual behavior, High school student, Cross sectional study, Aksum

\section{Introduction}

According to different sources the term youth refers to the age interval in between 15 and 24 years old and Since peoples become sexual active in this age interval healthy sexual awareness and development is mandatory for the future health status of the youths and adolescents in particular $[1,2]$. Healthy sexual development contributes for holistic personal well-being but if youths and adolescents become unaware of this they will develop different risky sexual behaviors [2-6].

Risky sexual behavior affects the youths and adolescents life style and contributes to different adverse effects, but as reports indicating its prevalence is increasing. One report indicates $41 \%$ adolescents had ever had sexual contact; from this number $43 \%$ didn't use any protective including condom the last time they had sex, $14 \%$

*Correspondence: hailemariamgirmay16@gmail.com School of Nursing, College of Health Science, Aksum University, Aksum, Ethiopia did not use any contraceptive, $21 \%$ had drunk alcohol before sexual intercourse $[4,7]$.

According to different studies adolescents are at high risk of developing risky sexual behavior with different environmental and communicational factors, for this case the global prevalence of HIV/AIDS which directly correlates with risk sexual behavior is increasing, sub Saharan countries are the most affected for this including Ethiopia with a prevalence of age $15-19$ years $(0.2 \%)$ and $20-24$ years $(0.9 \%)[5,8]$.

As the study in China the prevalence of risk sexual behavior was 42.4\%, even in Ethiopia risk sexual behavior among secondary school students was relatively high, for instance it was reported in Addis Ababa 26.7\% and especially in Debre-brhan, $6.7 \%$ of youths practiced sex with commercial sex workers $[5,9,10]$.

Despite of health policy maker's effort to create awareness and to reduce sexually transmitted infections (STI), contracting HIV/STIs is at an increasing rate. Since High school students are mainly in age group of 15-24, they are more exposed to risky sexual behavior [9]. 


\section{Main text}

\section{Study setting and period}

The study was conducted from March 18 to 25/2018 in Aksum town secondary and preparatory schools, which is located at $1024 \mathrm{~km}$ away from Addis Ababa. The total number of younger population in the town is estimated to be 44,260 out of which 24,292 of the total population is considered as adolescent.

\section{Study design, population and eligibility criteria}

Institutional based quantitative study design was applied. All systematically selected students from those registered for grade 9-12 and consented/assented were included in the study.

\section{Sample size calculation and Sampling Procedure}

The sample size was calculated using a single population proportion formula by considering the proportion of risky sexual practice as $71.2 \%$ [10] and 5\% margin of error, Correction formula since the total population was less than 10,000 which was 6939 and 1.5 design effect, sample size was calculated for different significant variables and finally 498 was obtained. Sample size has been allocated for every grade based on proportional allocation to their size. Finally students from every class had been selected by systematic random sampling $(\mathrm{k}=14)$.

\section{Data collection and analysis process}

Data were collected using a standardized and pre-tested self-administered questionnaire adapted from WHO sexual and Reproductive Health [11]. Experienced supervisors and data collectors were selected and trained prior to the survey. Completeness of each questionnaire had been checked. Double data entry was done and consistency of the entered data was cross checked by comparing the two separately entered data on Epi Data. Data were cleaned and entered to Epi Data version 3.0.2 and exported to SPSS version 22 for further analysis. Frequency, percentage, means and standard deviation was used for data description. Bivariate logistic regression was applied to identify associated factors then those with p-value $\leq 0.25$ were entered to multivariate logistic regression to get the significantly associated variables with $\mathrm{p}$-value $<0.05$.

\section{Variables, operational definitions and ethical issues}

The dependent variable was risky sexual behavior and the independent variables were socio demographic characteristics, Parental characteristics and other relevant data. The operational definition for risky sexual behavior was when a student practices at least one of the following, multiple sexual partners (having more than one sexual partner until the survey), early initiation of sex (sexual debut at the age $<18$ years old), inconsistent use of condom (inconsistent/fail to use condom at least ones during sexual intercourse until the survey), Sex with commercial sex workers at least once until the survey).

Ethical clearance had been obtained from Institutional review committee of Aksum University college of Health Science. Permission to conduct the research was obtained from local government authorities and school directors. Data were collected after full informed written consent/assent was obtained from each study subject's accordingly. When age was less than 16 years old, it obtained from parents/legal guardians of students. Confidentiality was secured and treated anonymous.

\section{Results}

Socio demographic characteristics of study participants

A total of 496 students completed the questionnaire yielding a total response rate of $99.6 \%$. Among those respondents, the large proportion 253 (51.1\%) were females by gender. The mean age of participants was 16.29 years $( \pm 1.45)$, ranging from 13 to 24 years old. Among the respondents $68.1 \%$ of the students were living with their parents and $405(82 \%)$ are raised by both parents (Table 1).

\section{Prevalence of risk sexual behavior}

One out of four 115 (23.7\%) of the students had ever practiced sexual intercourse and the mean age for sexual initiation was 15.48 year $( \pm 1.99) .110(98.2 \%)$ had sexual contact below the age of $18,30(26.3 \%)$ had $\geq 2$ life time sexual partner and $44(29.3 \%)$ had $\geq 2$ sexual partners in the last 12 months. Moreover $54(46.6 \%)$ hasn't been use condom consistently and 41 (35\%) had faced objection for condom use by their sexual partner. Overall 97 (19.6\%) had practiced risky sexual behaviors (Table 2).

\section{Factors associated with risk sexual behavior}

In the multivariate logistic regression by whom raised the student, discussion on SRH with parents, sex with Commercial sex workers, pocket money, peer pressure and pornographies had significant association with risky sexual behavior (Table 3).

\section{Discussion}

In Ethiopia, many studies have been conducted on risk sexual behavior in different population groups, however the issue was neglected among young secondary school students in the study area. Thus, this study was able to assess the prevalence of risk sexual behavior and associated factors among high school students in Aksum town.

From the surveyed students, $23.7 \%$ had ever practiced sexual intercourse and the mean age for sexual initiation was 15.48 year $( \pm 1.99)$, which is higher than the studies finding in China (7\%) [12], (13.8\%) India, (18.3\%) Aleta 
Table 1 Socio-demographic characteristics of secondary and preparatory school students of Aksum town, northern Ethiopia, $2018(n=496)$

\begin{tabular}{|c|c|}
\hline Variable $(n=496)$ & Frequency (\%) \\
\hline \multicolumn{2}{|l|}{ Age } \\
\hline $14-19$ & 479 (96.6) \\
\hline $20-24$ & $15(3.4)$ \\
\hline \multicolumn{2}{|l|}{ Sex } \\
\hline Male & $242(48.9)$ \\
\hline Female & $253(51.1)$ \\
\hline \multicolumn{2}{|l|}{ Level of education } \\
\hline Grade 9 & $203(41.0)$ \\
\hline Grade 10 & $228(46.1)$ \\
\hline Grade 11 & $44(8.90)$ \\
\hline Grade 12 & $20(4.0)$ \\
\hline \multicolumn{2}{|l|}{ Religion } \\
\hline Orthodox & $461(93.1)$ \\
\hline Muslim & $25(5.1)$ \\
\hline Protestant & $8(1.6)$ \\
\hline Catholic & $1(0.2)$ \\
\hline \multicolumn{2}{|l|}{ Ethnicity } \\
\hline Tigray & $437(88.3)$ \\
\hline Amhara & $39(7.9)$ \\
\hline Oromo & $19(3.8)$ \\
\hline \multicolumn{2}{|l|}{ Raised by } \\
\hline Both parents & $405(82)$ \\
\hline With father/mother & $13(2.6)$ \\
\hline Other relatives & $76(15.4)$ \\
\hline \multicolumn{2}{|l|}{ Currently live with } \\
\hline Both parents & $337(68.1)$ \\
\hline Father & $24(4.8)$ \\
\hline Mother & $77(15.6)$ \\
\hline Alone & $48(9.7)$ \\
\hline Others & $9(1.8)$ \\
\hline
\end{tabular}

wondo, (19\%) Shendi, and comparable with the study finding in North Gondar (23\%), lower than the studies finding in Colombia (25\%), (27.1\%) Gurage, (29\%) Wolaita, Bodetti, south Ethiopia (29.1\%), Assela (33.6\%), and South Africa (47\%) [9, 12-21]. The disparity might be due to difference in study participant Sociodemographic difference, difference in traditional and cultural background, and difference.

The prevalence of risk sexual behavior practice in this study is $19.6 \%$, which is comparable with study finding in assela 20\% [20], northwest Ethiopia 20.4\% [22], higher than the studies finding in Addis Ababa by Amsale Cherie et al. (10.6\%) [23], Humera (13.7\%) [24], Jijiga (16\%) [25], Bodetti, southern Ethiopia (17.9\%) [26], and lower than the studies finding in Nigeria (24.1\%) [27], Benishangul
Table 2 Parental and other related characteristics of secondary and preparatory school students of Aksum town, northern Ethiopia, $2018(n=496)$

\begin{tabular}{|c|c|}
\hline Variable $(n=496)$ & Frequency (\%) \\
\hline \multicolumn{2}{|l|}{ Father currently alive } \\
\hline Yes & $444(89.7)$ \\
\hline No & $51(10.3)$ \\
\hline \multicolumn{2}{|l|}{ Father's educational status } \\
\hline Can't read and write & $38(7.7)$ \\
\hline Read and write & $235(47.6)$ \\
\hline Elementary & $139(28.1)$ \\
\hline High school College and above & $82(16.6)$ \\
\hline \multicolumn{2}{|l|}{ Father's employment status } \\
\hline Employed & $247(50.3)$ \\
\hline Unemployed & $244(47.7)$ \\
\hline \multicolumn{2}{|l|}{ Mother currently alive } \\
\hline Yes & $466(94.1)$ \\
\hline No & $28(5.9)$ \\
\hline \multicolumn{2}{|l|}{ Mother's educational status } \\
\hline Can't read and write & $104(21.1)$ \\
\hline Read and write & $212(42.9)$ \\
\hline Elementary & $114(23.1)$ \\
\hline High school college and above & $64(13.0)$ \\
\hline \multicolumn{2}{|l|}{ Mother's employment status } \\
\hline Employed & $165(33.5)$ \\
\hline Unemployed & $328(66.5)$ \\
\hline \multicolumn{2}{|l|}{ Parents control students } \\
\hline Yes & $464(93.7)$ \\
\hline No & $31(6.3)$ \\
\hline \multicolumn{2}{|l|}{ Discuss on SRH issues with parents } \\
\hline Yes & $377(76.3)$ \\
\hline No & $117(24.7)$ \\
\hline \multicolumn{2}{|l|}{ Have you ever consumed alcohol } \\
\hline Yes & $114(23.0)$ \\
\hline NO & $381(77.0)$ \\
\hline \multicolumn{2}{|l|}{ Have you ever smoke cigarette } \\
\hline Yes & $23(4.6)$ \\
\hline No & $472(95.4)$ \\
\hline \multicolumn{2}{|l|}{ Pocket money per month } \\
\hline $1-150$ birr & $349(70.5)$ \\
\hline 151-250 birr & $62(12.5)$ \\
\hline $251-500$ birr & $30(6.1)$ \\
\hline$>500$ birr & $54(10.9)$ \\
\hline \multicolumn{2}{|l|}{ Peer pressure } \\
\hline Yes & 59 (11.9) \\
\hline No & $435(88.1)$ \\
\hline \multicolumn{2}{|l|}{ Ever seen/read pornography } \\
\hline Yes & $160(32.3)$ \\
\hline No & $335(67.7)$ \\
\hline \multicolumn{2}{|l|}{ Ever had sexual intercourse } \\
\hline Yes & $115(23.7)$ \\
\hline No & 376 (76.6) \\
\hline
\end{tabular}


Table 2 (continued)

\begin{tabular}{|c|c|}
\hline Variable $(n=496)$ & Frequency (\%) \\
\hline \multicolumn{2}{|c|}{ Age at first sex $(n=115)$} \\
\hline$<18$ years & $110(95.6)$ \\
\hline$>18$ years & $5(4.4)$ \\
\hline \multicolumn{2}{|c|}{ Relationship of first sexual partner } \\
\hline Boy/girlfriend & $84(73.7)$ \\
\hline Teacher & $30(25.3)$ \\
\hline Others & $1(1)$ \\
\hline \multicolumn{2}{|l|}{ Initiations of first sex } \\
\hline Own will & $68(60.8)$ \\
\hline Forced & $18(16.0)$ \\
\hline For money & $10(9.0)$ \\
\hline Materials/gifts & $16(14.2)$ \\
\hline \multicolumn{2}{|c|}{ Lifetime sexual partners } \\
\hline One & $84(73.7)$ \\
\hline Two and more & $30(26.3)$ \\
\hline \multicolumn{2}{|c|}{ Sexual partners in the last 12 month } \\
\hline One & $68(60.7)$ \\
\hline Two and more & $44(29.3)$ \\
\hline \multicolumn{2}{|c|}{ Ever had sex for cash or gift } \\
\hline Yes & $39(32)$ \\
\hline No & $83(68)$ \\
\hline \multicolumn{2}{|c|}{ Condom used for first sex } \\
\hline Yes & $65(55.6)$ \\
\hline No & $52(44.4)$ \\
\hline \multicolumn{2}{|c|}{ Suggestion for condom use } \\
\hline Myself & 45 (39.8) \\
\hline My partner & $24(21.2)$ \\
\hline Joint & $44(38.9)$ \\
\hline \multicolumn{2}{|c|}{ Use condom at last sexual intercourse } \\
\hline Yes & $56(48.7)$ \\
\hline No & $59(51.3)$ \\
\hline \multicolumn{2}{|c|}{ Consistence condom use } \\
\hline Yes & $62(53.4)$ \\
\hline No & $54(46.6)$ \\
\hline \multicolumn{2}{|c|}{ Partner's objection on condom use } \\
\hline Yes & $41(35.0)$ \\
\hline No & $76(65.0)$ \\
\hline
\end{tabular}

Gumuz (82.2\%) [28], Haramaya (65.8\%) [29], Addis Ababa by Abdusemed Mussa Ali (71.6\%) [30], (48.3\%) Dilla town [31], (70.5\%) Agena Guragae zone, Ethiopia [13] and (42.1\%) China [12]. This difference might be due to the approaches taken to quantify risky sexual behavior, study area variation and study participants Sociodemographic characteristics.

Those students not discussed on sexual reproductive health with parents are 3.4 times more likely to practice risky sexual behavior. In line with the finding in
Assela [20], Dilla town [31], Haromaya [32]; Benishangul Gumuz [28]; Metema [33], and in contrast to studies finding in bale goba [34], and Nepal [35]. This might be since majority of student preferred to discuss about sexual issues with their peers of the same sex than with their family members, even if they discussed with their family they may not give attention for the discussion or the discussion topics are limited and not to the satisfaction level of the students, as a result they may develop immature awareness, which contributes to the practice.

Students having sex with commercial sex workers are eighteen times more likely to practice risky sexual behavior. It is consistent with study finding in Benishangul Gumuz [28] but studies in Humera [24], Jimma [36], Haramaya [29] not supported the evidence. This might be since those CSWs have relation with many people, again many of them gives more attention for money than safety that means they are at high sexual risk, as adolescents have sexual relation with those people they are vulnerable for risky sexual behavior practice [24].

Respondents seeing pornographies are 6 times more likely practices risky sexual behavior. This is similar with the study finding in Jimma [36], Addis Ababa [30], Haramaya [32] and Humera [24] but in contrast in other study finding in Addis Ababa done by Gizaw et al. [10], and in Haramaya [37]. The possible reason for the discrepancy might be since some students may get experience on how to prevent risky sexual practice whereas other groups may be liable and need to enjoy what they observe in the film without any protection.

Students not facing peer pressure are $64 \%$ less likely practices risky sexual behavior. This is in line with study finding in Slovak [38], South Africa [39], Ghana [40], Addis Ababa [23], Assela [20] and humera [22], this might be due to their need to share life experiences with their peers, however, study in Addis Ababa by Gizaw et al. [10] revealed that peer pressure had no statistical significant effect, which might be due to self-efficacy of students to wards external force.

Students who got $<150$ Birr monthly pocket money had $66 \%$ less likely practices risky sexual behavior than those students who got monthly pocket money greater than 500 Birr. This might be due to the reason that when adolescents get money they may have opportunity to practice what they desire and the adolescents age interval demands high sexual desire, it is in contrast with the study finding in Bodetti, south Ethiopia which reports those didn't get money 1.2 times more likely to practice risky sexual behavior.

Respondents who rose by both parents had $54 \%$ less likely practices risky sexual behavior than those who rose by either of the parents $(\mathrm{AOR}=0.46(0.2,0.9)$. supported by findings in Slovakia [38], Sweden [41], Humera [22], 
Table 3 Factors associated with risk sexual behaviors of secondary and preparatory school students of Aksum town, northern Ethiopia, $2018(n=496)$

\begin{tabular}{|c|c|c|c|c|c|c|}
\hline \multirow[t]{2}{*}{ Variables } & \multicolumn{2}{|c|}{ Risk sexual behaviors } & \multirow[t]{2}{*}{ P-value } & \multirow[t]{2}{*}{ COR $(95 \% \mathrm{Cl})$} & \multirow[t]{2}{*}{ P-value } & \multirow[t]{2}{*}{ AOR $(95 \% \mathrm{Cl})$} \\
\hline & Yes & No & & & & \\
\hline \multicolumn{7}{|l|}{ Raised by } \\
\hline Both parents & 83 & 322 & 0.035 & $0.56(0.33,0.96)$ & 0.42 & $0.46(0.2,0.9)$ \\
\hline With father/mother & 4 & 9 & 0.95 & $0.96(0.27,3.4)$ & 0.31 & $2.2(0.47,10.8)$ \\
\hline Other relatives & 24 & 52 & 1 & 1 & 1 & 1 \\
\hline \multicolumn{7}{|l|}{ Discussion on SRH } \\
\hline Yes & 96 & 281 & 1 & 1 & 1 & 1 \\
\hline No & 15 & 102 & 0.005 & $2.3(1.3,4.2)$ & 0.001 & $3.42(1.6,7.3)$ \\
\hline \multicolumn{7}{|l|}{ Sex with CSWs } \\
\hline Yes & 23 & 3 & 0.001 & $33.2(9.7,113)$ & 0.001 & $18(4.0,75.4)$ \\
\hline No & 88 & 381 & 1 & 1 & 1 & 1 \\
\hline \multicolumn{7}{|l|}{ Monthly pocket money } \\
\hline $1-150$ birr & 65 & 287 & 0.01 & $0.29(0.16,0.5)$ & 0.02 & $0.34(0.13,0.84)$ \\
\hline 151-250 birr & 15 & 47 & 0.037 & $0.43(0.195,0.95)$ & 0.043 & $0.31(0.1,0.96)$ \\
\hline 251-500 birr & 11 & 19 & 0.596 & $0.78(0.3,1.95)$ & 0.86 & $1.2(0.3,3.9)$ \\
\hline$>500$ birr & 23 & 31 & 1 & 1 & 1 & 1 \\
\hline \multicolumn{7}{|l|}{ Peer pressure } \\
\hline Yes & 34 & 26 & 0.001 & $0.12(0.09,0.3)$ & 0.007 & $0.36(0.17,0.74)$ \\
\hline No & 77 & 358 & 1 & 1 & 1 & 1 \\
\hline \multicolumn{7}{|c|}{ Seen pornographic movies } \\
\hline Yes & 75 & 85 & 0.001 & $7.3(4.6,11.7)$ & 0.001 & $5.9(3,11.47)$ \\
\hline No & 36 & 299 & 1 & 1 & 1 & 1 \\
\hline
\end{tabular}

Jimma [36], benishangul Gumuz [42], western Ethiopia [43], African countries [44], Haromaya [29].

\section{Conclusions}

In this study the prevalence of risky sexual behavior reported as $19.6 \%$, discussion on SRH with parents, raised by both parents and $<150$ birr monthly pocket money had preventive significant association. Peer pressure, seeing pornographies and sex with CSWs had significant association with increasing risk sexual behavior.

\section{Limitations}

Since the topic is sensitive issue there may be over reporting or under reporting and due to the nature of the study design may not show cause and effect so that it should be repeated with different study design.

\section{Abbreviations}

Cl: confidence interval; AOR: adjusted odd ratio; SPSS: Statistical Package for Social Sciences.

\section{Acknowledgements}

We would like to thank all study participants and data collectors for their contribution in success of our work.

\section{Authors' contributions}

AG conceived and designed the study, analyzed the data and wrote the manuscript. TM participated in Data analysis, drafting of the manuscript and advising the whole research paper. AG and TM were involved in the interpretation of the data and contributed to manuscript preparation. TM and AG involve in title selection, data analysis, drafting of the manuscript. Both authors read and approved the final manuscript.

\section{Funding}

There is no funding for this research. All cost of data collection and analysis were covered by the authors.

\section{Availability of data and materials}

The data sets used and/or analyzed during the current study available from the corresponding author on reasonable request.

\section{Ethics approval and consent to participate}

The study was reviewed and approved by the research committee of health Science College of Aksum University. Consent also obtained from educational office of the town and further from directors of each school. The objective and important of the study was explained to the study participants. Moreover, Respondents were assured of Information provided and giving the choice not to participate in the study. Data were collected after full informed written consent/assent was obtained from each study subjects/when age was less than 16 years old, it obtained from parents/legal guardian. In order to keep confidentiality of the data, name was not included.

Consent to publish

Not applicable.

\section{Competing interests}

This manuscript maintains no competing financial interest declaration from any person or Organization or non-financial competing interests such as 
political, personal, religious, ideological, academic, intellectual, commercial or any other.

Received: 3 June 2019 Accepted: 10 October 2019

Published online: 26 October 2019

\section{References}

1. Crossette B, Kollodge R. State of world population 2011-people and possibilities in a world of 7 billion. New York, 2011. Published by UNFPA; 2011. http://www.unfpa.org/public/home/news/pid/8769.

2. Gilbert-Roberts T-A. CARICOM governance of youth development: prospects for regional citizenship. Soc Econ Stud. 2014;63(3\&4):59-106.

3. Snyder TD, Dillow SA. Digest of education statistics, 2008. Washington, DC: Government Printing Office; 2009

4. Montgomery MR, Stren R, Cohen B, Reed HE. Cities transformed: demographic change and its implications in the developing world. Abingdon: Routledge; 2013.

5. Organization WH. Joint United Nations Programme on HIV/AIDS (UNAIDS) - WHO: revised recommendations for the selection and use of HIV antibody tests. Wkly Epidemiol Rec. 1997;72(12):81-7.

6. Folayan MO, Odetoyinbo M, Brown B, Harrison A. Differences in sexual behaviour and sexual practices of adolescents in Nigeria based on sex and self-reported HIV status. Reprod Health. 2014;11(1):83.

7. Abera A. Factors affecting the performance of micro and small enterprises in Arada and Lideta Sub-Cities, Addis Ababa. MBA Thesis unpublished, School of Graduate Studies, Addis Ababa University, Ethiopia; 2012

8. Macro I, Measure D. Ethiopia demographic and health survey 2011: preliminary report. Central Statistical Agency and ICF Macro: Addis Ababa, Ethiopia and Calverton, Maryland, USA. 2011

9. Kann L, Kinchen S, Shanklin SL, Flint KH, Hawkins J, Harris WA, et al. Youth risk behavior surveillance_-United States, 2013. Morb Mortal Wkly Rep Surveill Summ. 2014:63(4):1-168.

10. Gizaw A, Jara D, Ketema K. Risky sexual practice and associated factors among high school adolescent in Addis Ababa, Ethiopia, 2014. Fam Med Med Sci Res. 2014;3:4. https://doi.org/10.4172/2327-4972.1000141.

11. Cleland J, Ingham R, Stone N. Special programme of research, development and research training in human reproduction. UNDP/UNFPA/WHO/ World Bank; 2001

12. Li S, Huang H, Xu G, Cai Y, Huang F, Ye X. Substance use, risky sexual behaviors, and their associations in a Chinese sample of senior high school students. BMC Public Health. 2013;13(1):295.

13. Deyessa N, Tesfaye G. Intention to use condom among students in Agena preparatory school, Guraghe Zone, Ethiopia: with the application of health believe model. Arch Public Health. 2013;71(1):23.

14. Tekletsadik E, Shaweno D, Daka D. Prevalence, associated risk factors and consequences of premarital sex among female students in Aletawondo High School, Sidama Zone, Ethiopia. J Public Health Epidemiol. 2014;6(7):216-22.

15. Yohannes B, Gelibo T, Tarekegn M. Prevalence and associated factors of sexually transmitted infections among students of Wolaita Sodo University, Southern Ethiopia. Int J Sci Technol Res. 2013;2(2):86-94.

16. Campo-Arias A, Ceballo GA, Herazo E. Prevalence of pattern of risky behaviors for reproductive and sexual health among middle-and high-school students. Revista latino-americana de enfermagem. 2010;18(2):170-4.

17. Tsehay S, Mulatie M, Sellakumar K. Risky sexual behavior among adolescent students in north Gondar. Citeseer: Ethiopia; 2014.

18. Bogale A, Seme A. Premarital sexual practices and its predictors among in-school youths of shendi town, west Gojjam zone, North Western Ethiopia. Reprod Health. 2014;11(1):49.

19. Daka D, Shaweno D. Magnitude of risky sexual behavior among high school adolescents in Ethiopia: a cross-sectional study. J Public Health Epidemiol. 2014;6(7):211-5.

20. Assefa N, Tejineh S, Zelalem H. Substance use and factors associated with risky sexual practice in school youth in Asella Town, South-East Ethiopia, 2017. J Public Health Epidemiol. 2017;10(1):6-15.
21. Shashikumar R, Das R, Prabhu H, Srivastava K, Bhat P, Prakash J, et al. A cross-sectional study of factors associated with adolescent sexual activity. Indian J Psychiatry. 2012;54(2):138.

22. Bizu D, Aderaw Z, Kassa GM. Assessment of early sexual initiation and associated factors among preparatory school students of FaggetaLekoma District, Awi Zone, Northwest Ethiopia, 2015. Int J Clin Med. 2015;6(8):521.

23. Cherie A, Berhane Y. Peer pressure is the prime driver of risky sexual behaviors among school adolescents in Addis Ababa, Ethiopia. World J AIDS. 2012:2(03):159.

24. Dadi AF, Teklu FG. Risky sexual behavior and associated factors among grade 9-12 students in Humera secondary school, western zone of Tigray, NW Ethiopia, 2014. Sci J Public Health. 2014;2(5):410-6.

25. Mavhandu-Mudzusi AH, Tesfay Asgedom T. The prevalence of risky sexual behaviours amongst undergraduate students in Jigjiga University, Ethiopia. health sa gesondheid. 2016;21(1):179-86.

26. Daka D, Shaweno D. Magnitude of risky sexual behavior among high school adolescent students in Ethiopia, cross sectional study. J Public Health Epidemol. 2014:31:211-5.

27. Ajuwon AJ, Olaleye A, Faromoju B, Ladipo O. Sexual behavior and experience of sexual coercion among secondary school students in three states in North Eastern Nigeria. BMC Public Health. 2006;6(1):310.

28. Agajie M, Belachew T, Tilahun T, Amentie M. Risky sexual behavior and associated factors among high school youth in Pawe Woreda, Benishangul Gumuz Region. Sci J Clin Med. 2015;4(4):67-75.

29. Derese A, Seme A, Misganaw C. Assessment of substance use and risky sexual behaviour among Haramaya University Students, Ethiopia. Sci J Public Health. 2014;2(2):102-10.

30. Ali M. Risky sexual behavior and factors associated with it among public and private secondary school students in Addis Ababa City (Ethiopia): a cross-sectional comparative study. J Gynecol Reprod Med. 2017;1 (1):1-10

31. Abosetugn AE, Zergaw A, Tadesse H, Addisu Y. Correlations between risky sexual behavior and parental communication among youth in Dilla town, Gedeo zone, South Ethiopia. Biol Med. 2015;7(5):1.

32. Shore H, Shunu A. Risky sexual behavior and associated factors among youth in Haramaya Secondary and Preparatory School, East Ethiopia, 2015. J Public Health Epidemiol. 2017;9(4):84-91.

33. Tiruneh K, Wasie B, Gonzalez H. Sexual behavior and vulnerability to HIV infection among seasonal migrant laborers in Metema district, northwest Ethiopia: a cross-sectional study. BMC Public Health. 2015;15(1):122.

34. Teferra TB, Erena AN, Kebede A. Prevalence of premarital sexual practice and associated factors among undergraduate health science students of Madawalabu University, Bale Goba, South East Ethiopia: institution based cross sectional study. Pan Afr Med J. 2015;20(1):209.

35. Adhikari N, Adhikari S. Attitude towards premarital sex among higher secondary students in Pokhara Sub-Metropolitan City. J Community Med Health Educ. 2017;7:564. https://doi.org/10.4172/2161-0711.1000564

(Page 2 of $6 \mathrm{~J}$ Community Med Health Educ, an open access journal ISSN: 2161-0711 Volume 7, Issue 5, 1000564. were in early adolescent stage ie age group of. 2017:14-6).

36. Tura G, Alemseged F, Dejene S. Risky sexual behavior and predisposing factors among students of Jimma University, Ethiopia. Ethiop J Health Sci. 2012;22(3):11.

37. Dingeta T, Oljira L, Assefa N. Patterns of sexual risk behavior among undergraduate university students in Ethiopia: a cross-sectional study. Pan Afr Med J. 2012;12(1):33.

38. Kalina O. Sexual risky behaviour among Slovak adolescents and young adults: social and psychological factors: University Library Groningen] [Host]; 2012.

39. Amoateng AY, Kalule-Sabiti I, Arkaah YJ. The effect of socio-demographic factors on risky-sexual behaviours of adolescents in the North West Province of South Africa. Afr Popul Stud. 2014;28(1):487-98.

40. Bingenheimer JB, Asante $\mathrm{E}$, Ahiadeke C. Peer influences on sexual activity among adolescents in Ghana. Stud Fam Plann. 2015;46(1):1-19.

41. Asamoah BO, Agardh A. Individual-and family-level determinants of risky sexual behavior among Swedish-and foreign-born young adults 18-30 years of age, residing in Skåne, Sweden. Arch Sex Behav. 2018;47(2):517-28.

42. Yesus DG, Fantahun M. Assessing communication on sexual and reproductive health issues among high school students with their parents, Bullen Woreda, Benishangul Gumuz Region, North West Ethiopia. Ethiop J Health Dev. 2010. https://doi.org/10.4314/ejhd.v24i2.62956. 
43. Negeri EL. Assessment of risky sexual behaviors and risk perception among youths in Western Ethiopia: the influences of family and peers: a comparative cross-sectional study. BMC Public Health. 2014;14(1):301.

44. Biddlecom A, Awusabo-Asare K, Bankole A. Role of parents in adolescent sexual activity and contraceptive use in four African countries. Int Perspect Sex Reprod Health. 2009;35:72-81.

\section{Publisher's Note}

Springer Nature remains neutral with regard to jurisdictional claims in published maps and institutional affiliations.
Ready to submit your research? Choose BMC and benefit from:

- fast, convenient online submission

- thorough peer review by experienced researchers in your field

- rapid publication on acceptance

- support for research data, including large and complex data types

- gold Open Access which fosters wider collaboration and increased citations

- maximum visibility for your research: over $100 \mathrm{M}$ website views per year

At BMC, research is always in progress.

Learn more biomedcentral.com/submissions 